\section{JURIES IN FRAUD TRIALS: A STRONG CASE FOR CHANGE}

The use of juries in fraud trials is under discussion again. In answer to the retentionist argument that any lack of understanding by juries can be addressed through better presentation of the prosecution's case, the Lord Chancellor was reported in the Financial Times last month as saying: 'That is very often a pious hope in relation to the staggering complexity of some of these trials.'

In 1986 Lord Roskill's Fraud Trials Committee recommended, with Walter Merricks's famous dissent, that for complex fraud cases trial by judge and two lay assessors should replace trial by judge and jury. Lord Runciman's Royal Commission on Criminal Justice reported that there was no evidence that a change would lessen the risk of a mistaken verdict, but recommended a change in the law to allow research and an informed debate rather than argument based on surmise and anecdote.

Lord Justice Auld has now reviewed the arguments for and against change. Those against include the democratic nature of the jury and its random selection ensuring fairness and independence. It is also said that mostly the question is one of dishonesty which juries are well-equipped to decide and practitioners with fraud experience consider that jury verdicts are in the main 'correct'. Also, the existence of the jury forces the parties to present their cases in simple and easily digestible form.

In favour of change it is said that jurors are not generally experienced in commercial procedures. Without this experience it is difficult for them sufficiently to understand the context in which the alleged offence has been committed and, therefore, to determine whether there has been dishonesty. It is also said that the length of trials is an unreasonable intrusion on jurors' personal and working lives. Many can find grounds for being excused from service, and, as a result, juries are often even less representative than would otherwise be the case. When tried before a lay jury the case is necessarily lengthened and judges and specialist assessors would be able to deal justly and more expeditiously with such cases at correspondingly lower cost. Lastly, the reformists say a tribunal would produce a publicly reasoned and appealable decision which is not available from a jury.

The Serious Fraud Office was set up as part of the reforms following Roskill in 1988. Since then it has brought to trial several hundred of the most serious and complex cases. It brings together in multidisciplinary teams all the necessary legal, accountancy and investigative skills. Fewer serious frauds are escaping prosecution, and because the one organisation is

\section{Articles}

Shifting the balance of power: civil liberties and access to justice in the 21 st century

The Law Society and the Bar: can they be trade unions, brand managers and public watchdogs at the same time?

\section{News}

FLAG: the news Internet gateway to foreign law. Hold up in UK national and university libraries

E-banking and authentiction 20

Powers and process in Revenue Law 22 26

responsible for all stages of the process the investigation can be geared to produce a manageable prosecution from the start.

With the Court of Appeal's encouragement to judges to use the power of severance to secure a manageable and fair trial, the Office has framed indictments with due regard to the limitations of jury trial. The Office has not overloaded indictments, and has endeavoured to reflect in the charges sufficient criminality to enable juries on the evidence to convict with confidence. To assist juries the Office and prosecuting counsel have developed techniques for presenting and explaining complex financial evidence to non-experts. However, in spite of these changes the Director of the Serious Fraud Office has said that the average length of trials is still six months, and some have taken more than a year before the jury.

So, 16 years on from Roskill is it, in the light of our experience over that period, time for change? Lord Justice Auld finds the arguments in favour the more persuasive, and would give the trial judge power to direct trial by himself sitting with lay members or, where the defendant has opted for trial by judge alone, by himself. Indeed, he considers the arguments in favour of reform have become more pressing over the last 16 years given the ever-lengthening and complex nature of fraud trials together with their increasingly specialised nature and international ramifications. The fact that the administrative, procedural and evidential reforms of the Roskill Committee which were substantially enacted in the Criminal Justice Act 1987 have not significantly reduced the problems of jury trial now makes the need for change compelling.

\section{George Staple QC}

